\title{
REACTIVE POWDER CONCRETE AND ITS APPLICATION IN COMPOSITE STRUCTURES
}

Ján Bujňák ${ }^{1}$
Stefania Grzeszczyk

UDK: 666.972 .12

DOI: $10.14415 /$ konferencijaGFS2021.01

Summary: Reactive powder concrete (RPC), typically with higher compressive strength, is particularly attractive to structural engineers to apply them in infrastructures for enhancing their resistance under severe environments and loads. The main objective of the initial study presented in the paper is to investigate the behavior of two types of these new cementitious materials differing in the nature of microfibers. The RPC mixes were reinforced with steel and then with basalt microfibers. To evaluate the structural performance of developed unconventional materials, properties were investigated experimentally and compared with the control normal concrete mix. The high RPC strength may enable particularly effective joints in composite structures consisting of steel girders and precast concrete slabs. The investigation of such shear connection efficiency, using test specimens was also executed. Finite element numerical models were developed. The outputs of the studies are presented in the paper.

Keywords: Reactive powder concrete, material property tets, composite element, numerical modeling.

\section{INTRODUCTION}

Reactive Powder Concrete (RPC) is one of the most advanced cement-based composite materials with a compressive strength going from $80 \mathrm{MPa}$ to $200 \mathrm{MPa}$ and flexural one ranging between $30 \mathrm{MPa}$ and $50 \mathrm{MPa}$. The composite is also characterized by high tensile strength, excellent impact as well as abrasion resistance and can provide extraordinary durability [1]. Thanks to these properties, RPC is increasingly being used in widely understood composite structures in which layers of concrete of different classes are joined together. Also composite steel-concrete flooring elements can be considered as one of the most economical systems for building, particularly for greater spans allowing better use of internal space without restricting columns. Especially trusses are appropriate to meet the requirements for construction height limitation as well as the need to run complex electrical, heating, ventilating, and communication systems. Similarly composite steel bridges, whose carriageway concrete deck is supported on a filigree steel truss structure and slim piers, are particularly preferable to ordinary

\footnotetext{
${ }^{1}$ Ján Bujňák, prof. Ing. PhD., University of Zilina, Faculty of Civil Engineering, Univerzitná 8215/1, 01026

Žilina, ,Slovakia, tel: +421 41 51352,e - mail: jan.bujnak@uniza.sk

2 Stefania Grzeszczyk, prof. dr hab., Opole University of Technology, Faculty of Civil Engineering, Katowicka 48, 45061 Opole, Poland, tel: +48 77 4498598, e - mail: s.grzeszczyk@po.edu.pl
} 
Савремена достигнућа у грађевинарству 22-23. април 2021. Суботица, СРБИЈА

structural systems. But design specifications of composite trusses are only partially included in actual standards. In this case, the longitudinal forces are introduced into the concrete slab only locally in the nodes, where the web members are connected to the compressed chord [2]. The phenomenon of slippage at the steel-concrete interface depends on many factors, including of the type and size of the shear connectors, their spacing, the type of concrete slab and the strength of the concrete at the location of the connectors. Combining shear connectors and RPC in these locations can be an effective solution to prevent the relative slip at the steel-concrete interface, when particularly precast deck is used. As it may be uneconomical to make a concrete slab entirely of such concrete, the use of RPC to fill element joints with steel shear connectors seems greatly appropriate.

\section{RPC PROPERTIES STUDY}

In the introductory study, three groups of mixes were prepared. The control concrete series (C) have examined the samples behavior without fibers. Two new RPC sets contained steel fibers (S) or unconventional basalt fibers (B). ). Portland cement CEM I $52.5 \mathrm{R}$ was employed. Moreover ingredients and admixtures have replaced obvious coarse aggregate. Especially silica quartz powder $0-0.2 \mu \mathrm{m}$ and silica sand $0-0.4 \mathrm{~mm}$ were also used as additives. The study involves two different RPC materials. At first with steel fibers $12 \mathrm{~mm}$ long and $0.2 \mathrm{~mm}$ in diameter were spread in mixture for development of RPC. Basalt fibers of $12 \mathrm{~mm}$ length with $18 \mu \mathrm{m}$ thickness were used for the other innovative testing. A polycarboxylate superplasticizer was added at a ratio 2.5 $\%$ of cement weight to fluidify the mixture. By using this superplasticizer, it was possible to reduce water and cement ratio $(\mathrm{w} / \mathrm{c})$ at the value only about 0.2 . In this way a significant part of the cement was not hydrated. Improved granular compactness through the use of powders and silica fume with a complementary grain size distribution eliminated the presence of a transition zone between sand and slurry particles and ensured very low porosity of the material.

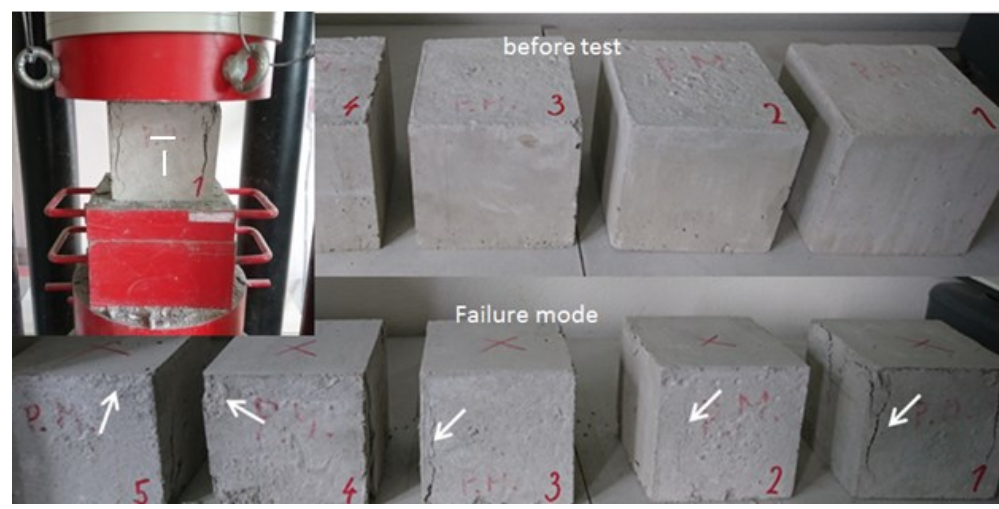

Figure 1. Concrete specimen in the testing machine with cracks appeared 
Contemporary achievements in civil engineering 22-23. April 2021. Subotica, SERBIA

The experimental work started in mixing, casting and testing the mechanical properties of ordinary and high-strength concrete. Consequently thus, three sets of specimens for mechanical properties testing were prepared to determine the compressive and flexural strength as well as elastic modulus of ordinary concrete but also RPC with addition of steel or basalt fibers. Three sets of concrete cubes $(150 \mathrm{~mm} \times 150 \mathrm{~mm} \times 150 \mathrm{~mm})$ were prepared. Each set consisted of 3 specimens, cast in steel molds and demolded $24 \mathrm{~h}$ later. Figure 1 gives the concrete specimen on the testing machine producing predominantly compression.

The mean compressive strengths of six specimens produced from both categories of RPC as well as values of three ordinary concrete samples are summarized in Table 1. The experimental values show only slight variations of the fibers reinforced materials strength. The average round strength value can be considered as $120 \mathrm{~N} / \mathrm{mm}^{2}$. The studies even confirmed that incorporating microfibers into the mixtures resulted in higher early compressive strength.

Table 1.Result of concrete compressive strength measurement.

\begin{tabular}{ccccccc}
\hline \multirow{2}{*}{$\begin{array}{c}\text { Specimen } \\
\text { type }\end{array}$} & \multicolumn{3}{c}{ Dimensions } & Unit mass & Ultimate force & $\begin{array}{c}\text { Compressive } \\
\text { strength }\end{array}$ \\
\cline { 2 - 5 } & $\begin{array}{c}\text { Contact area } \\
{[\mathrm{mm}]}\end{array}$ & {$[\mathrm{mm}]$} & {$[\mathrm{mm}]$} & {$\left[\mathrm{kg} / \mathrm{m}^{3}\right]$} & {$[\mathrm{kN}]$} & {$\left[\mathrm{N} / \mathrm{mm}^{2}\right]$} \\
\hline 1 B-27-06 & 154,6 & 150,5 & 150,3 & 2390 & 3014,05 & 129,54 \\
2 B-25-06 & 151,5 & 150,0 & 150,1 & 2400 & 2510,00 & 110,45 \\
3 B-25-06 & 153,8 & 150,1 & 150,0 & 2390 & 3168,93 & 137,27 \\
\hline 4 S-27-06 & 150,1 & 149,5 & 150,0 & 2158 & 2945,47 & 131,26 \\
\hline 5 S-27-06 & 150,1 & 150,2 & 150,0 & 2208 & 2893,40 & 129,46 \\
6 S-27-06 & 150,1 & 150,2 & 150,2 & 2263 & 2960,67 & 132,47 \\
\hline 7 C-25-06 & 147,1 & 148,9 & 149,2 & 2382 & 697,5 & 31,87 \\
\hline 8 C-25-06 & 149,2 & 146,8 & 150,0 & 2398 & 682,5 & 31,16 \\
\hline 9 C-25-06 & 148,8 & 147,7 & 150,2 & 2346 & 674,9 & 30,71 \\
\hline
\end{tabular}

The cube specimens were also used to determine other material characteristics. They were instrumented with four strain gages in the opposite sides. Two of them were used for vertical strain measurement and the further two for transversal horizontal strain recording. During the compressive tests, the load history was measured by universal testing machine while the strains of the specimen were obtained by averaging two sideways gages values, as shown in Figure 1. Thus Poisson's ration could be identified. In linear range, this ratio rises from 0.18 to 0.20 .

The Young's modulus $E$ computed with the longitudinal strains on the elastic part of the behavior was $54 \mathrm{GPa}$ and in the case of basalt microfibers slight less $47 \mathrm{GPa}$. Damages, accompanied by a reduction in the modulus values, only have occurred above $50 \%$ of the ultimate average compressive strength.

The tensile behavior can be determined from load - deflection curve obtained by applying a center - point load on a simply supported notch prism. It tests the ability of unreinforced concrete beam to withstand failure in bending. The test specimens were two prisms per composition, totally six ones conforming to EN 12390-1 [3] with standard width and depth of $150 \mathrm{~mm}$ and the length $600 \mathrm{~mm}$. In Figure 2, test arrangements and testing for flexural strength of beam in the laboratory can be observed. 

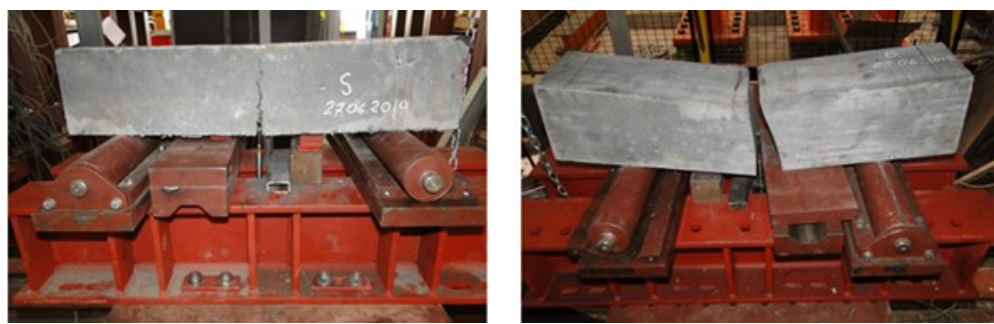

Figure 2. The layout of flexural strength test in the laboratory

Device for transmitting load of the testing machine to the test specimen consisted of two supporting rollers and one loading pin. The span length as the distance between the centers of the supporting rollers was equal to $500 \mathrm{~mm}$. Testing machine has applied loads at a uniform rate and continuously without shock till the point of failure at a constant rate $4 \mathrm{kN} /$ minute. The wet sawing has been used to notch the test specimens in the mid - span section. The width of the notch was $4 \mathrm{~mm}$. Linear displacement traducers with a measured displacement accuracy of $0.01 \mathrm{~mm}$ have been installed in the mid span to register specimen deflections.

The experimental force - deflections curve for specimens reinforced with steel microfibers consisted generally from the linear - elastic part of the diagram up to $75 \%$ of applied load. The progressive tensile damage beyond this point makes the curve diverge from the straight line. Nevertheless microfibers reinforcement could redistribute the stress between initiated micro - cracking, which did not lead to precipitate failure of the specimen. But multiple propagated micro - cracks ended at the peak of the load deflection curve. The strains were localized in a single crack opening in the mid - span, where final failure occurred. The average flexural strength on all RPC standard beams specimens were $25.46 \mathrm{~N} / \mathrm{mm}^{2}$. The application of fibers in conventional concrete as supplementary cementitious material to an appropriate amount was seen and exhibits better mechanical behavior.

\section{TESTING OF COMPOSITE ELEMENT}

Potential employment of the RPC to attach particularly precast concrete decks to steel superstructure was subject of the subsequent study. The shear capacity and the load slip relations are the most important characteristics for the design of this type of composite structures. The suitable method to found the shear connection properties could be full - scale composite beam tests, but quite a time consuming and rather costly [4]. Therefore push - out test were primarily implemented in the research [5]. During this experimental investigation, the local shear force has been applied to a concrete specimen. The transfer of the resulting shear force between the steel section and concrete slabs was provided by shear studs incased in RPC.

The test specimens consisted of a steel shape HEB 260B and two concrete slab attached to the flanges of the steel beam. The concrete slab were $650 \mathrm{~mm}$ long, $600 \mathrm{~mm}$ wide attached using four stud connectors with a shank diameter of $16 \mathrm{~mm}$ and $75 \mathrm{~mm}$ in height to each flange. The longitudinal distance between the connectors was $96 \mathrm{~mm}$ and 
Contemporary achievements in civil engineering 22-23. April 2021. Subotica, SERBIA

transversal pitch $56 \mathrm{~mm}$. Two test specimens $\mathrm{C} 1$ and $\mathrm{C} 2$ included both slab of the ordinary concrete $\mathrm{C} 25 / 30$. In the case of specimens S1 and S2, the RPC mortar was added a blend of micro smooth steel fiber. The specimens B1 and B2 were prepared with the addition of basalt fibers. As shown in Figure 3, shear connections was completed by casting and filling in the square holes with RPC mortar of compressive strength of 120 $\mathrm{N} / \mathrm{mm}^{2}$.
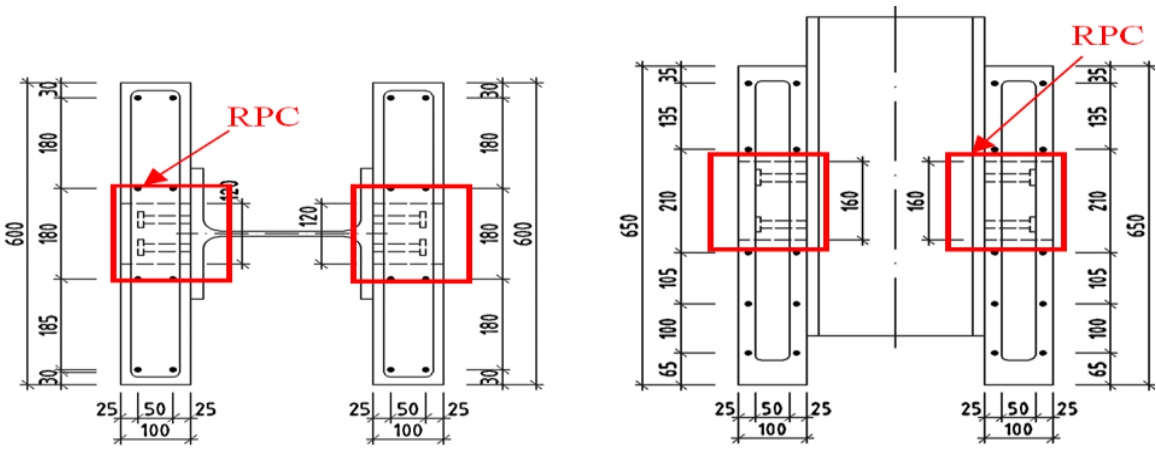

Figure 3. Push-out specimen of RPC with steel S1 and basalt B1 fibers

The slabs were bedded down directly onto the reaction floor with load being applied to the upper end of the member. All tests were conducted using a universal testing machine. The load was applied in increments of $20 \mathrm{kN}$ from 0 to $160 \mathrm{kN}$ (40\% of the expected failure load), then returned to $40 \mathrm{kN}$ (5\% of the expected failure load). After the loading cycle between $40 \mathrm{kN}$ and $200 \mathrm{kN}$ was repeated 25 times. The displacement controlled load continued up to the failure at the speed of $1 \mathrm{~mm}$ in 2 minutes. At each load or displacement increments, the slip history between two concrete slabs and the steel beam was measured by linear variable transformers and recorded. Its average value was plotted against the load per connector.
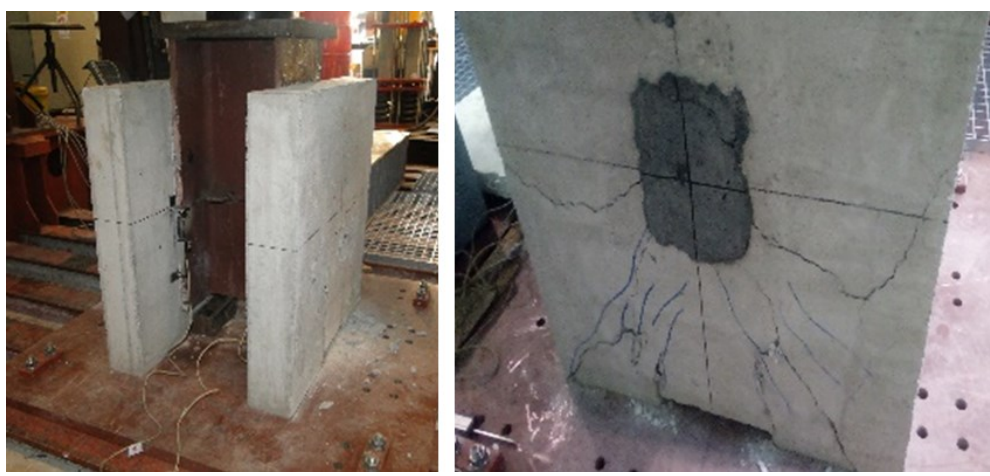

Figure 4. Specimen in testing machine and ultimate failure cracking

During 25 cycles (between $40 \mathrm{kN}$ et $200 \mathrm{kN}$ ), both specimens $\mathrm{C} 1$ and $\mathrm{C} 2$ stayed in good condition, the slabs and the steel beam worked well together, the cracks had not yet been 
Савремена достигнућа у грађевинарству 22-23. април 2021. Суботица, СРБИЈА

developed at that time. At the end of the 25th cycle loading was changed from load control to slip control. At the load of $300 \mathrm{kN}$, the interface between steel and concrete was delaminated and the slip of $0.4 \mathrm{~mm}$ was achieved. Beyond the load of $400 \mathrm{kN}$, the cracks began to appear in the slabs. The test was ended with the shear of the connectors at the load of $543 \mathrm{kN}$ and the ultimate slip value of $3 \mathrm{~mm}$, as illustrated in Figure 5
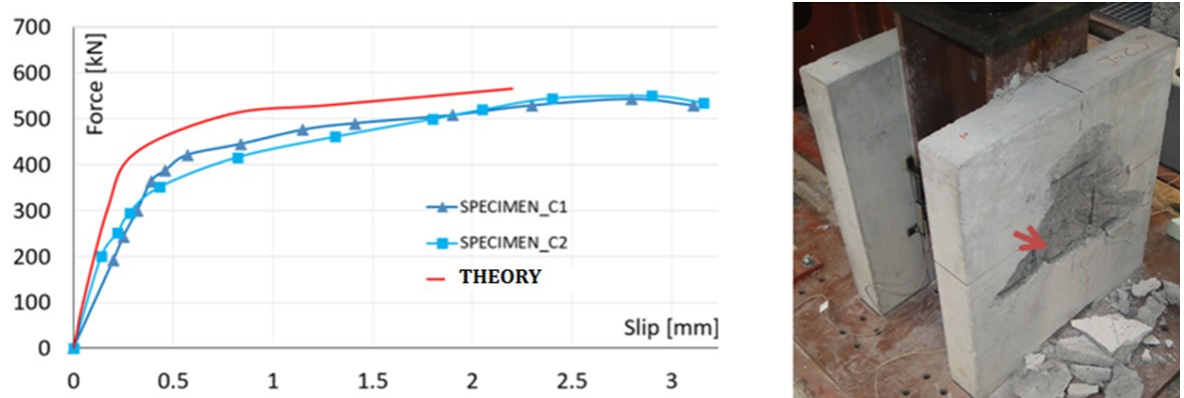

Figure 5. Load-slip curves of the ordinary concrete pus-out specimens, failure mode

The failure of the second sets of four RPC specimen occurred by cracking of surrounding low - strength normal concrete with shear of the connectors at the ultimate load about $41 \%$ superior. The corresponding history of loading and slip development is slight different as demonstrated in Figure 6, including rather changed failure mode.
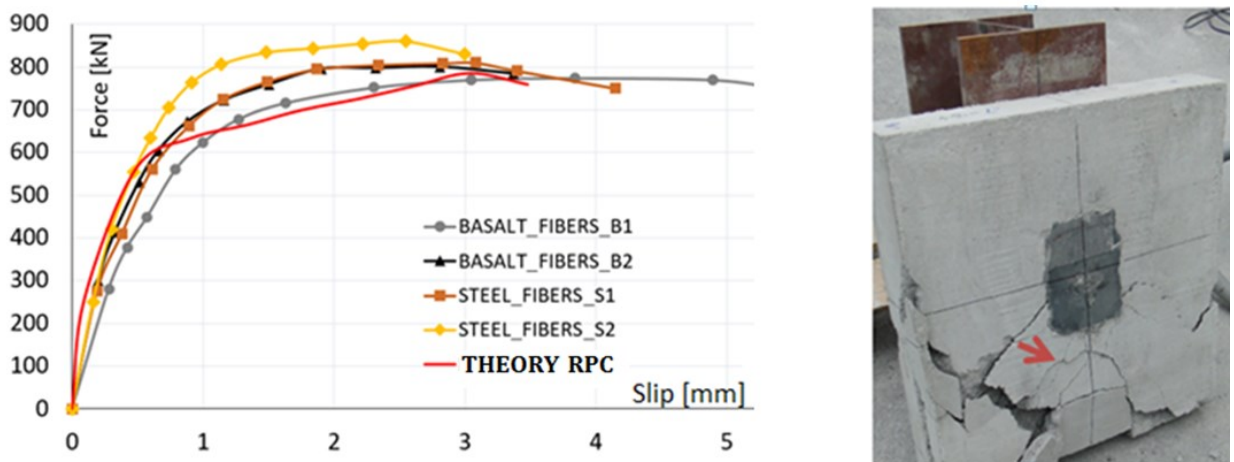

Figure 6. Load-slip curves of the RPC push-out specimen and its failure mode

\section{COMPOSITE TRUSS BEAM TESTS}

Four similar steel-concrete composite truss beams V1 to V4 of span $3.75 \mathrm{~m}$ were prepared to analyse the global behaviour of steel-concrete composite trusses. Steel truss components were made from the steel S235. Upper chord of the beam was prepared from $1 / 2$ IPE 160 , bottom chord from two welded UPE 120 in box component. The web members at lateral parts consisted of square hollow section SHS $70 \times 70 \times 6.3$ and the 
Contemporary achievements in civil engineering 22-23. April 2021. Subotica, SERBIA

middle diagonals of the square hollow section SHS $40 \times 40 \times 3$. Concrete slab of size $800 \times 100 \mathrm{~mm}$ was made with demand on concrete grade C25/30. Transversal and longitudinal reinforcement was formed from the bars $\phi 10$. Shear connection was provided by headed stud of diameter $10 \mathrm{~mm}$ and height $50 \mathrm{~mm}$ located only above the nodes as shown in Figure 7. Loading was applied in the thirds of span above nodes.

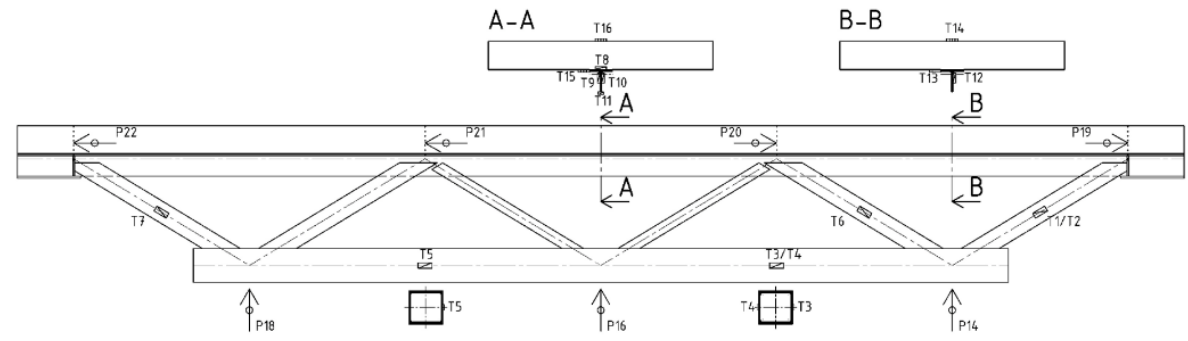

Figure 7. Components of composite truss specimen

Strains were recorded in both chords and web members of the girders as well as concrete slab by system of sixteen strain gauges. The details positions of the devices in cross sections are labelled as T1 to T16. During the testing, the end slips of concrete slab have been measured using displacement sensors as P19 to P22. The deflection transducers were situated at the girders ends as well as in the middle P16 and near the quarter part of span. Data received from the strain gauge package were digitized and sent to the notebook. This computer was used to communicate with the measurement system for commands regarding data acquisition, calibration, initialization, downloading and display.
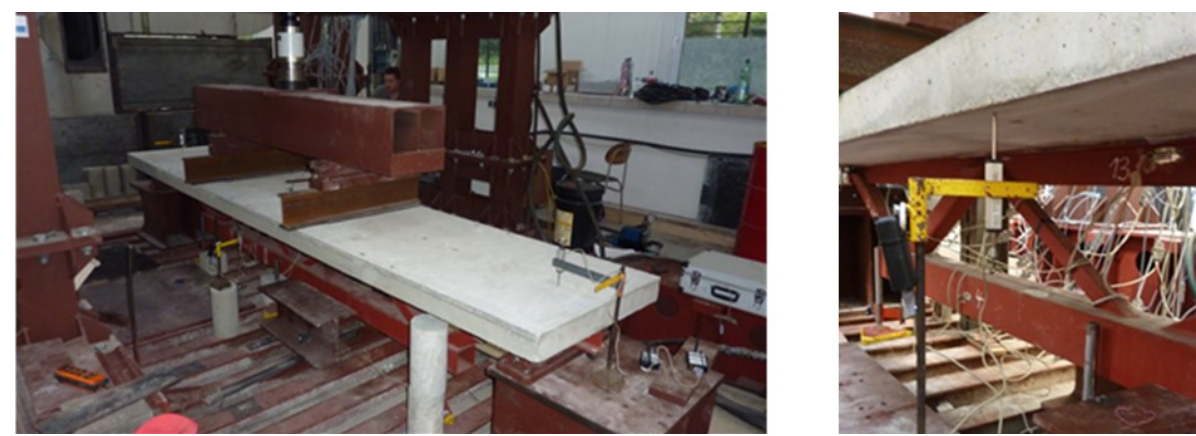

Figure 8. Loading and measurement system

The recorded deflections in the truss beams V1 to V3 have been initially developing proportionally till the loading level of $325 \mathrm{kN}$, as it can be seen in Figure 9a. The whole truss deflections under supplementary loading have been growing slightly nonlinearly and produced the ultimate permanent vertical deflection of $33 \mathrm{~mm}$ at the end of test. As alternative, the composite truss beam V4 had its upper chord cut out and the 
corresponding pressures were taken over simply by the concrete deck. Its load - carrying capacity has dropped to about half of the previous values, as shown in Figure 9b.

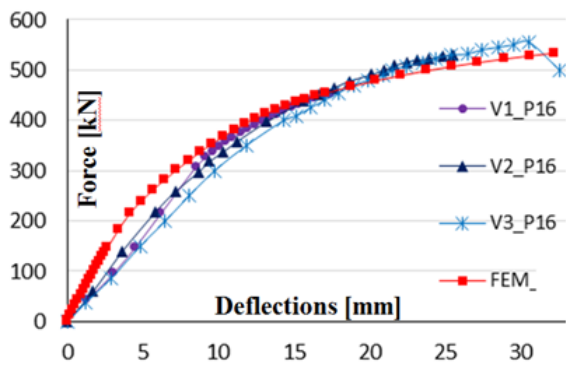

(a)

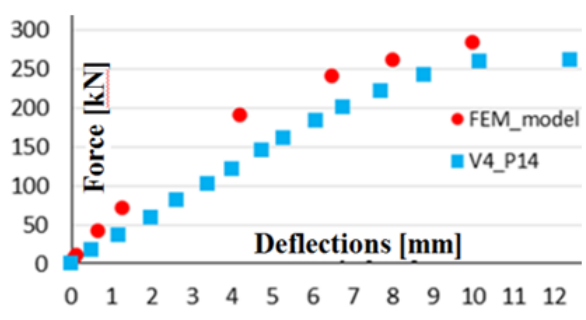

(b)

Figure 9. Load deflection relationships of V1 to V3 and V4 trusses

In both cases, the limit state has been achieved at the load value under which the connectors in the support zone happening to fail by shearing. In this stage, the connectors in span were only somewhat distorted by bending thanks to favourable loading.

\section{NUMERICAL MODELLING OF TESTING}

Theoretical model of connection behavior in the experimental tests has been created using nonlinear analysis provided by ADINA software, offering numerous possibilities to simulate various particularities of the concrete and steel properties. Even though, shear connection modelling has required some modification to consider more appropriately real interaction at the interface of the concrete slab and steel part as the main problem of nonlinear analysis. Beside the composite action of both constitutive parts and headed studs modelling, it was necessary to include contribution effect of the contact shear surface, obviously simply neglected [6].

As illustrated in Figure 10, the three-dimensional four-node tetrahedral isoparametric elements were used to substitute numerically adjacent concrete slabs. The mesh used to represent steel beam web and flanges consisted of shell elements. The circular shapes of the stud connectors head and shank were approximated by a hexagon and $0.005 \mathrm{~m}$ of the element size. Concrete behavior of slab in the push-out specimens was treated as an elastic-plastic material that was offered by the software. Only the average measured value of $f_{c m}=28 \mathrm{~N} / \mathrm{mm}^{2}$ was set-up and entered as only one known input concrete property and the other values have been calculated by ATENA. The headed stud model has behaved like linear elastic material with modulus $\mathrm{E}=210000 \mathrm{~N} / \mathrm{mm}^{2}$ up to the yield stress $f_{y}=360 \mathrm{~N} / \mathrm{mm}^{2}$. After reaching this value, the steel becomes fully plastic. The steel beam was modelled in this study with yield stress $f_{y}=235 \mathrm{~N} / \mathrm{mm}^{2}$ using analogous bilinear curve.

Figure 5 shows the comparison between the load-slip curves obtained experimentally and numerically using the finite element method. The curve obtained from numerical 


\section{$8^{\text {th }}$ inTERnATIONAL CONFERENCE}

Contemporary achievements in civil engineering 22-23. April 2021. Subotica, SERBIA

modelling is called THEORY. Theoretical and experimental values of slip confirm a good agreement between the test and the numerical model in the range of practically applied loading. The first crack in concrete slab was initiated at the force value of $54 \mathrm{kN}$. The following cracking propagation, under small load up to $223 \mathrm{kN}$ did not modified linear behavior remarkably. The theoretically declared ultimate loading capacity was 573 $\mathrm{kN}$. The corresponding damaged areas are plotted in Figure 10.
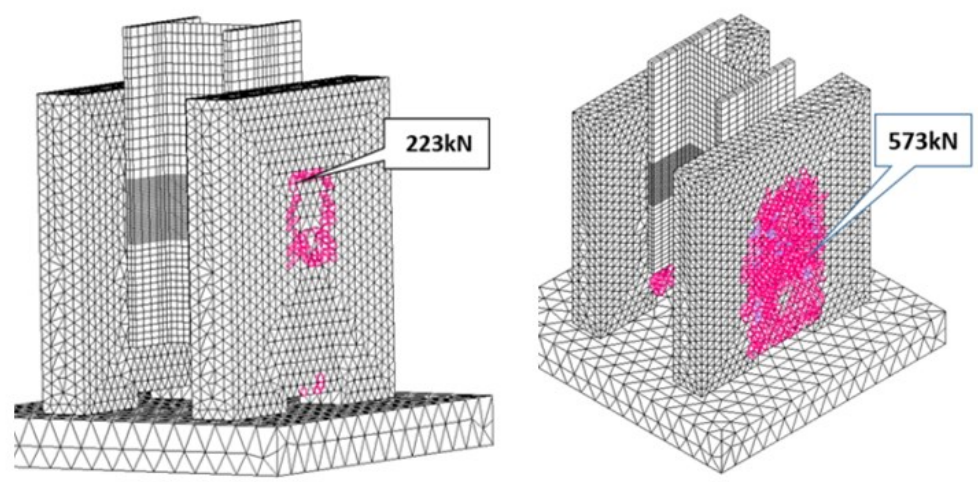

Figure 10. Finite model of the ordinary concrete push - out specimen

For both type of RPC push-out specimens, the experimental slips similarly initially were increasing proportionally to the slightly higher loading level of $273 \mathrm{kN}$, as shown in Figure 11. However, with increasing load, the diagrams present new faster overall slip development. The slips under supplementary loading were around $3.5 \mathrm{~mm}$ at the end of test and the ultimate force value of $788 \mathrm{kN}$, so by a third larger than in the case of ordinary concrete. Finally the connection failed by cracking in ordinary concrete slab parts without RPC encasement local damages, as well as no shear connector defects, as shown in Figure 4 or 6 . Thus the bending failure of connectors does not need to be taken in consideration, due to favorable load transmission by RPC encasement.
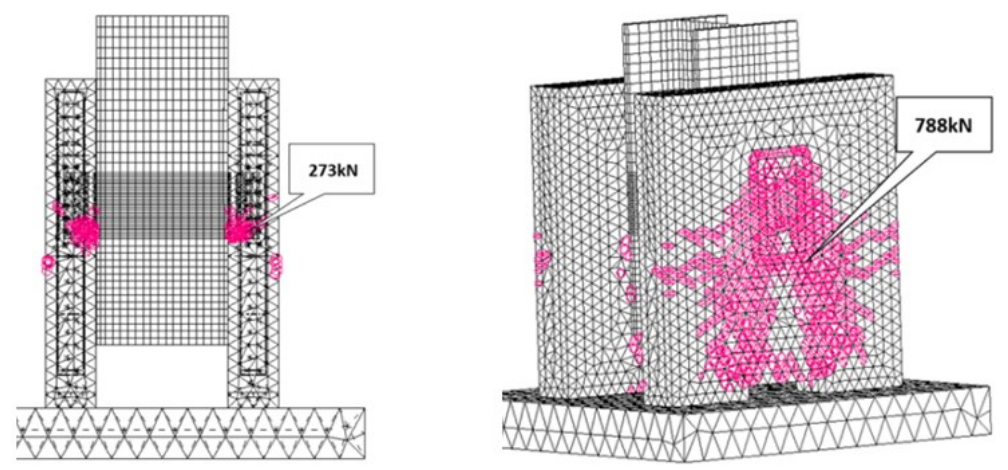

Figure 11. Modelling of RPC push - out specimen 
Савремена достигнућа у грађевинарству 22-23. април 2021. Суботица, СРБИЈА

The figure 12 shows as an example the finite computational model of the truss beam. Also suitably describes the zones of failure of the concrete deck working alone as upper truss cord.

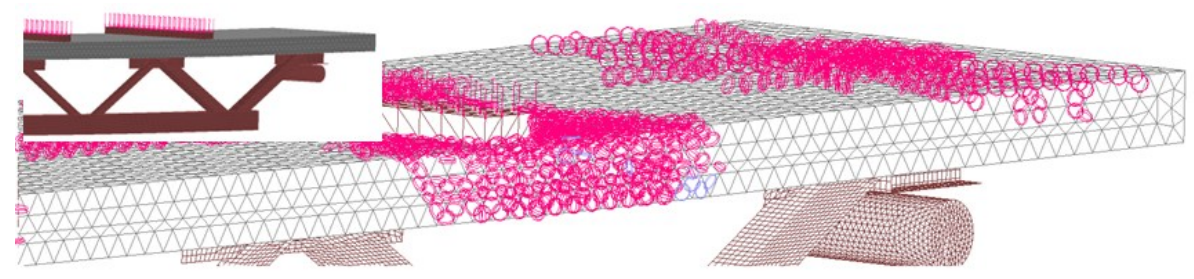

Figure 12. Modelling of RPC truss specimen

The supplementary comparison of results can be judged also as rather good, considering the extremely complex behavior of material grouping and composite action.

\section{CONCLUSION}

In this study, two reactive powders concrete reinforced with the steel or basalt fibers were evaluated for structural applications. Experimental study of mechanical properties and push-out as well as truss testing revealed higher mechanical and cracking resistances of RPC used for shear connection of precast structural elements in comparison with normal low-strength concrete. Also, the RPC aggregates can meet the requirements for compressive strength and other mechanical properties for use in structural applications after being cured in the conventional condition.

\section{REFERENCES}

[1] Grzeszczyk, S., Matuszek-Chmurowska, A., Cerný, R., Vejmelková, E.: Microstructure of reactive powder concrete, Journal of Cement Wapno Beton, 2018, vol. 83, p.p 1-15.

[2] Bujnak, J.: Composite structures of steel and concrete, Zilina University Publishing House, Zilina, Slovakia, 2016. Book.

[3] EN 12390-1.Testing hardened concrete - Part 1: Shape, dimensions and other requirements for specimens and mold, 2012. CEN Brussels.

[4] Bujnak,J.; Duratna, P.; Bouchair,A. Theoretical and Experimental research on Composite Truss Beams, Proceedings of the 7th European Conference on Steel and Composite Structures, Napoli, Italy 2014.,p.p. 505-512.

[5] Bujnak,J., Duratna, P., Bouchair,A.: Connection in Steel-Concrete Composite Truss, Proceedings of the 23rd Czech and Slovak International Conference on Steel structures and bridges, e-Journal Procedia Engineering 2012., vol. 40, p.p 96-101.

[6] Michalek,P.: Concept of selected types of composite steel and concrete truss structures, University of Zilina 2020. Doctoral thesis 